\title{
Influence of commercially available follicle stimulating hormone on the in vitro maturation of bovine oocytes
}

\author{
Influência do hormônio folículo-estimulante disponível \\ comercialmente sobre a maturação in vitro de oócitos bovinos
}

\author{
Maria Valéria de Oliveira Santos ${ }^{1} ;$ Luiza Bento de Queiroz Neta ${ }^{1}$; \\ Alana Azevedo Borges ${ }^{1}$; Alexsandra Fernandes Pereira ${ }^{2 *}$
}

\begin{abstract}
The work aimed (Experiment I) to compare commercial representations of porcine follicle stimulating hormone (FSH, Pluset ${ }^{\circledR} v s$. Folltropin $\left.{ }^{\circledR}\right)$ in concentration $(10 \mu \mathrm{g} / \mathrm{mL})$ and time $(24 \mathrm{~h})$ standard (more used in protocols of in vitro maturation, IVM); (Experiment II) to evaluate the best incubation time ( $6 \mathrm{~h}$ $v s .16 \mathrm{~h} v s .24 \mathrm{~h}$ ) and, (Experiment III) to analyze varying concentrations $(1.0 \mu \mathrm{g} / \mathrm{mL} v s .2 .5 \mu \mathrm{g} / \mathrm{mL} v s$. $10.0 \mu \mathrm{g} / \mathrm{mL}$ ) of representations of FSH on the IVM of bovine oocytes. Thus, oocytes were recovered and submitted to IVM under appropriate conditions. After the IVM, oocytes were evaluated for expansion of cumulus cells (CCs), presence of the first polar body (1PB) and metaphase plate (MII). All the data were analyzed by the Fisher exact test $(\mathrm{P}<0.05)$. Initially, in Experiment I, no difference $(\mathrm{P}>0.05)$ was observed in maturation rates of the oocytes incubated with FSH Pluset ${ }^{\circledR}$ or Folltropin ${ }^{\circledR}$, assessed by expansion of CCs (97.6\% vs. 94.3\%), presence of 1PB (76.6\% vs. 69.4\%) and MII (70.0\% vs. 68.6\%). In Experiment II, when the incubation time with FSH was evaluated, both Pluset ${ }^{\circledR}$ as Folltropin ${ }^{\circledR}$ showed lower rate of expansion of CCs when they were present only in the first $6 \mathrm{~h}$ of IVM. As for presence of $1 \mathrm{~PB}$, differences were observed in relation to Pluset ${ }^{\circledR}$ while Folltropin ${ }^{\circledR}$ showed similar results in all incubation times. Regarding the MII, no difference was observed between the incubation times with FSH Pluset ${ }^{\circledR}$ and Folltropin ${ }^{\circledR}$. In Experiment III, no difference was observed in the expansion of CCs, presence of 1 PB and MII for concentrations evaluated FSH Pluset ${ }^{\circledR}$ and Folltropin ${ }^{\circledR}$. Therefore, the FSH Pluset ${ }^{\circledR}$ and Folltropin ${ }^{\circledR}$ have the same efficiency in IVM of bovine oocytes. Regarding the incubation time, it is recommended to maintain FSH (Pluset ${ }^{\circledR}$ or Folltropin ${ }^{\circledR}$ ) throughout the period of IVM, since there was no difference in the results of presence of MII. Furthermore, the concentration of $1.0 \mu \mathrm{g} / \mathrm{mL}$ of FSH Pluset ${ }^{\circledR}$ and Folltropin ${ }^{\circledR}$ is as effective as $10 \mu \mathrm{g} / \mathrm{mL}$ and can therefore be used for IVM of oocytes.
\end{abstract}

Key words: Cattle. Gonadotropin. In vitro production of embryos. Oocytes.

\section{Resumo}

O trabalho objetivou (Experimento I) comparar representações comerciais do hormônio folículo estimulante suíno (FSH, Pluset ${ }^{\circledR} v s$. Folltropin $\left.{ }^{\circledR}\right)$ na concentração $(10 \mu \mathrm{g} / \mathrm{mL})$ e tempo $(24 \mathrm{~h})$ padrão (mais utilizados nos protocolos de maturação in vitro, MIV); (Experimento II) avaliar o melhor tempo de incubação (6 h vs. 16 h vs. 24 h) e, (Experimento III) analisar concentrações variáveis $(1,0 \mu \mathrm{g} / \mathrm{mL}$ vs. $2,5 \mu \mathrm{g} / \mathrm{mL} v s .10,0 \mu \mathrm{g} / \mathrm{mL}$ ) das representações de FSH sobre a MIV de oócitos bovinos. Para tanto, oócitos foram recuperados e submetidos a MIV em condições adequadas. Após a MIV, oócitos foram avaliados quanto à expansão das células do cumulus $(\mathrm{CCs})$, presença do primeiro corpúsculo polar $(1 \mathrm{CP})$ e placa metafásica (MII). Todos os dados foram analisados pelo teste exato de Fisher $(\mathrm{P}<0,05)$.

\footnotetext{
${ }^{1}$ Discentes, Universidade Federal Rural do Semi-Árido, UFERSA, Mossoró, RN, Brasil. E-mail: valeriasnts07@gmail.com; luizabentoqueiroz@gmail.com; alanaazevedob@gmail.com

2 Prof., Universidade Federal Rural do Semi-Árido, UFERSA, Mossoró, RN, Brasil. E-mail: ale_lfcr@yahoo.com.br

* Author for correspondence
} 
Inicialmente, no Experimento I, nenhuma diferença foi observada $(P>0,05)$ nas taxas de maturação de oócitos incubados com FSH Pluset ${ }^{\circledR}$ ou Folltropin $\AA$, avaliadas pela expansão das CCs $(97,6 \%$ vs. 94,3\%), presença de $1 \mathrm{CP}(76,6 \%$ vs. 69,4\%) e MII (70,0\% vs. 68,6\%). No Experimento II, quanto ao tempo de incubação com FSH foi avaliado, tanto Pluset ${ }^{\circledR}$ quanto Folltropin ${ }^{\circledR}$ mostraram uma menor taxa de expansão de $\mathrm{CCs}$ somente nas primeiras $6 \mathrm{~h}$ de $\mathrm{MIV}$. Quanto à presença de $1 \mathrm{CP}$, diferenças foram observadas em relação ao Pluset ${ }^{\circledR}$ enquanto o Folltropin ${ }^{\circledR}$ mostrou resultados similares em todos os tempos de incubação. Em relação à MII, nenhuma diferença foi observada entre os tempos de incubação com o FSH Pluset ${ }^{\circledR}$ e Folltropin ${ }^{\circledR}$. No Experimento III, nenhuma diferença foi observada na expansão das CCs, presença do 1CP e MII para as concentrações avaliadas de FSH Pluset ${ }^{\circledR}$ e Folltropin ${ }^{\circledR}$. Portanto, FSH Pluset ${ }^{\circledR}$ e Folltropin ${ }^{\circledR}$ tem a mesma eficiência na MIV de oócitos bovinos. Em relação ao tempo de incubação, é recomendado manter o FSH (Pluset ${ }^{\circledR}$ or Folltropin ${ }^{\circledR}$ ) ao longo do período da MIV, uma vez que nenhuma diferença foi observada nos resultados da presença de MII. Além disso, a concentração de $1,0 \mu \mathrm{g} / \mathrm{mL}$ de FSH Pluset ${ }^{\circledR}$ e Folltropin ${ }^{\circledR}$ é tão eficiente quanto a $10 \mu \mathrm{g} / \mathrm{mL}$ e pode, portanto, ser usada para a MIV de oócitos.

Palavras-chave: Bovino. Gonadotrofina. Produção in vitro de embriões. Oócitos.

\section{Introduction}

The in vitro embryo production (IVEP) comprises several steps ranging from oocyte retrieval until the in vitro development of embryos in which each step has a direct influence on the final result. Briefly, the main stages of IVEP are: recovery, selection and in vitro maturation (IVM) of cumulus-oocyte complexes (COCs), IVF of COCs matured, in vitro development (IVD) of presumptive zygotes, transfer and birth of offspring. The IVM step may be considered critical for the success of IVEP (RIOS et al., 2015), since in besides being the first stage of culture itself, it is also responsible for providing the necessary factors for the oocytes undergo modifications necessary for embryonic development (MACHATY et al., 2012).

During the IVM, FSH plays a key role in the acquisition of competence for fertilization and embryo in vitro development (SIRARD et al., 2007; XIAO et al., 2014). The addition this hormone in the IVM medium increases mRNA expression of FSH receptors (rFSH) and $\mathrm{LH}$ receptors (rLH) in cumulus cells (CCs) (XIAO et al., 2014). However, some factors may influence the performance of FSH on these cells, as the source of FSH, which is directly related to their degree of purification and biological activity. This hormone may be extracted from the urine of women after menopause (HOOMANS et al., 1999), the pituitary extract of domestic animals, especially porcine (pFSH) and sheep (oFSH), and by recombinant DNA technology using ovarian lineage chinese hamster cells for recombinant human FSH; rhFSH (CALDER et al., 2003). Same after purification, urinary FSH or derived from pituitary displays a low degree of purity, with varying amounts of other hormones related to fertility, primarily LH (HOOMANS et al., 1999; LISPI et al., 2006). When it comes to origin FSH for IVM of bovine oocytes, the most used are of porcine origin with different proportions of FSH:LH (ALVES et al., 2001; CALDER et al., 2003; KAKKASSERY et al., 2010).

Studies have shown that the origin and concentration of this FSH in the medium of IVM may influence the maturation rates in different species: porcine (BING et al., 2001), equine (BORGES et al., 1998), cattle (CALDER et al., 2003) sheep (SHIRAZI et al., 2010). Additionally, it was observed that the addition of FSH may increase the competence of oocytes in just a few hours during initiation of IVM (KHAN et al., 2015). Thus, it is necessary to establish the optimum incubation time of this hormone (SIRARD et al., 2007), according to commercial representation. Therefore, this study aimed to: i) compare commercial representations of FSH porcine origin with different degrees of purification (proportion of FSH:LH); ii) evaluate the incubation time and iii) analyze different FSH concentrations of representations of IVM of bovine oocytes. 


\section{Material and Methods}

This study was approved by the Ethics Committee of Animal Use the Federal Rural University of SemiArid (CEUA/UFERSA, n² 23091.001069/2015-79). Unless otherwise indicated, reagents were purchased from Sigma-Aldrich (St. Louis, MO, USA) and the $\mathrm{pH}$ of the media was adjusted to 7.2-7.4.

\section{Experimental design}

This study evaluated the influence of commercial representations of FSH, Folltropin ${ }^{\circledR}$ and Pluset ${ }^{\circledR}$, on the IVM. The Folltropin ${ }^{\circledR}$ has $84 \%$ of FSH and $16 \%$ of LH (5.25:1) in its composition. Already the Pluset ${ }^{\circledR}$ contains $50 \%$ of FSH and LH (1:1). Thus, three experiments were performed. In the first experiment, comparison of different commercial representations of FSH (Pluset ${ }^{\circledR} v s$. Folltropin $\left({ }^{\circledR}\right)$ to $10 \mu \mathrm{g} / \mathrm{mL}$ for $24 \mathrm{~h}$ was performed; in the second experiment, evaluation of different incubation times ( $6 \mathrm{~h} v s .16 \mathrm{~h} v s .24 \mathrm{~h}$ ) with $10 \mu \mathrm{g} / \mathrm{mL}$ of Pluset巴 FSH or Folltropin ${ }^{\circledR}$ FSH during IVM was employed and last experiment, analysis of different concentrations $(10 \mu \mathrm{g} / \mathrm{mL}$ vs. $2.5 \mu \mathrm{g} / \mathrm{mL}$ vs. $1.0 \mu \mathrm{g} / \mathrm{mL})$ of Pluset ${ }^{\circledR}$ or Folltropin ${ }^{\circledR}$ FSH was carried out with the best time stablished in the second experiment. After the IVM, all oocytes were evaluated for the expansion of cumulus cells (CCs), the presence of the first polar body (1PB) and presence of the metaphase plate (MII).

\section{Recovery of immature oocytes}

Bovine ovaries were collected of female with reproductive history unknown in local slaughterhouse and transported to the laboratory in saline solution $(\mathrm{NaCl}, 0.9 \%)$ plus antibiotics (penicillin, $0.05 \mathrm{mg} / \mathrm{mL}$ ) at $35-37{ }^{\circ} \mathrm{C}$. In the laboratory, oocyte collection was performed using the follicular aspiration technique. All visible follicles of 2-8 $\mathrm{mm}$ diameter were aspirated for the recovery of structures. The procedure was performed using a $21 \mathrm{G}$ needle attached to a syringe of $5.0 \mathrm{~mL}$ containing selection medium [TCM199HEPES; $2.2 \mathrm{~g} / \mathrm{L}$ sodium bicarbonate; $0.2 \mathrm{mM}$ sodium pyruvate; $40 \mu \mathrm{g} / \mathrm{mL}$ gentamicin sulfate and 10\% fetal bovine serum (FBS; Gibco, Kentucky, USA)]. From the follicular content, oocytes were retrieved and classified under stereomicroscope and only the COCs having more than one layer of CCs and homogeneous cytoplasm (GONÇALVES et al., 2008) were considered viable and used for IVM.

\section{In vitro maturation (IVM)}

The IVM was performed in selection medium supplemented with $100 \mu \mathrm{M}$ cysteamine and FSH according to each experiment. Selected structures were divided into drops $(100 \mu \mathrm{L})$ covered with mineral oil and grouped in 30-40 COCs per drop for $24 \mathrm{~h}$ at $38.5{ }^{\circ} \mathrm{C}$, humidified atmosphere of $5 \%$ $\mathrm{CO}_{2}$. To analyze the incubation period of FSH (Experiment 2) after $6 \mathrm{~h}$ and $16 \mathrm{~h}$ of incubation, COCs were rapidly washed and transferred to drops of IVM medium without FSH to complete the maturation time of $24 \mathrm{~h}$.

\section{Evaluation of oocyte maturation}

After IVM, the COCs were evaluated for expansion of CCs under stereomicroscope. Subsequently, they were denuded by repeated pipetting in selection medium for the observation of the presence of 1PB. Thus, oocytes with expanded CCs and presence of 1PB were considered matured.

The nuclear development of oocytes was assessed using the Hoechst 33342. To this end, denuded oocytes were fixed in $4 \%$ paraformaldehyde in PBS for $30 \mathrm{~min}$ and washed in PBS containing 0.4\% bovine serum albumin (BSA). Then staining was performed with Hoechst $33342(10 \mu \mathrm{g} / \mathrm{mL})$ for 15 min to visualization in fluorescence microscope. Finally, oocytes presenting nucleus in metaphase II (metaphase plate, MII) were considered matured and those in other nuclear phases (as prophase I, metaphase I, anaphase I and telophase I) were considered immature. 


\section{Statistical analyses}

Maturation rates, calculated by the number of oocytes presenting expanded CCs, presence of $1 \mathrm{~PB}$ and MII on the total evaluated oocytes and resulting from different groups were analyzed by Fisher exact test using Graphpad Software INSTAT 3.06 (GraphPad Software Inc., La Jolla, USA). Data were expressed as percentage mean \pm standard error of the mean and the differences were considered statistically significant when $\mathrm{P}<0.05$. For all evaluations, five replicates were considered for the analysis of data.

\section{Results}

Initially, in the first experiment, there was no difference $(\mathrm{P}>0.05)$ in oocyte maturation rates incubated with Pluset ${ }^{\circledR}$ or Folltropin ${ }^{\circledR}$ FSH evaluated by the expansion of CCs, presence of $1 \mathrm{~PB}$ and presence of MII (Table 1). Therefore, having seen that there was no difference in efficiency between FSH provenances tested; other experiments were carried out to establish the parameters of time and concentration of the two commercial representations.

Table 1. Evaluation bovine oocytes incubated with different representations of FSH (Folltropin ${ }^{\circledR} v s$. Pluset ${ }^{\circledR}$ ).

\begin{tabular}{lcc}
\hline \multirow{2}{*}{ Evaluation of IVM } & \multicolumn{2}{c}{ Commercial representation (FSH:LH) } \\
\cline { 2 - 3 } & Pluset ${ }^{\circledR}(\mathbf{1 : 1 )}$ & Foltropin® (5,25:1) \\
\hline Cumulus cell expansion & $97.6 \pm 1.4(120 / 123)$ & $94.3 \pm 3.1(116 / 123)$ \\
Presence of the first polar body & $76.7 \pm 5.2(89 / 116)$ & $69.4 \pm 5.0(84 / 121)$ \\
Presence of metaphase plate & $70.0 \pm 3.8(70 / 100)$ & $68.6 \pm 5.3(70 / 102)$ \\
\hline
\end{tabular}

Mean on $\% \pm$ standard error $(n)$. $\mathrm{P}>0.05$.

In experiment 2, using FSH Pluset ${ }^{\circledR}$ (Table 2), a lower percentage of expansion of CCs was observed in oocytes incubated with FSH only the first $6 \mathrm{~h}$ of IVM in comparing the time of $16 \mathrm{~h}$. Nevertheless, the time of $24 \mathrm{~h}$ showed no difference compared to other times. Regarding the presence of $1 \mathrm{~PB}$, a better result was obtained after $24 \mathrm{~h}$ of incubation in the presence of FSH compared to the time of $6 \mathrm{~h}$, which did not differ from the time $16 \mathrm{~h}$. In the analysis of MII (Figure 1), no difference was observed in any of the time period $(\mathrm{P}>0.05)$. Thus, numerically $24 \mathrm{~h}$ showed a higher number of oocytes in virtually all parameters.

Already, after the IVM with FSH Folltropin ${ }^{\circledR}$ for different periods of incubation (Table 2), higher rate $(\mathrm{P}<0.05)$ expansion of $\mathrm{CC}$ s were obtained from oocytes maintained in the presence of FSH for $16 \mathrm{~h}$ and $24 \mathrm{~h}$. Regarding the presence $1 \mathrm{~PB}$ and $\mathrm{MII}$, there was no difference between time periods $(\mathrm{P}>0.05)$. Therefore, the result numerical time of $24 \mathrm{~h}$ showed a greater number of oocytes by staining with Hoechst (more precise parameter of IVM analysis). Thus, due to the results obtained and greater operational ease for the next experiment time of $24 \mathrm{~h}$ was used for both commercial representations evaluated in this study.

In experiment 3, when the FSH Pluset $\AA$ and Folltropin ${ }^{\circledR}$ were evaluated according to concentration, there was no difference $(\mathrm{P}>0.05)$ on none of the evaluated parameters (Table 3 ). 
Table 2. In vitro maturation of bovine oocytes incubated with Pluset ${ }^{\circledR}$ FSH (FSH/LH 1:1) and Folltropin ${ }^{\circledR}$ FSH (FSH:LH, 5,25:1) for different times (6 $\mathrm{h} v s .16 \mathrm{~h} v s .24 \mathrm{~h}$ ).

\begin{tabular}{lcccccc}
\hline \multirow{2}{*}{ Evaluation of IVM } & \multicolumn{2}{c}{ Pluset ${ }^{\circledR}$ FSH (FSH/LH, 1:1) } & \multicolumn{2}{c}{ Folltropin ${ }^{\circledR}$ FSH (FSH:LH, 5,25:1) } \\
\cline { 2 - 7 } & $\mathbf{6 ~ h}$ & $\mathbf{1 6 ~ h}$ & $\mathbf{2 4} \mathbf{~ h}$ & $\mathbf{6 ~ h}$ & $\mathbf{1 6 ~ h}$ & $\mathbf{2 4 ~ h}$ \\
\hline \multirow{2}{*}{ Cumulus cell expansion } & $95.8 \pm 1.3$ & $100 \pm 0.0$ & $97.5 \pm 1.7$ & $86.1 \pm 7.5$ & $100 \pm 0.0$ & $97.3 \pm 3.1$ \\
Presence of the first polar & $(114 / 119)^{\mathrm{a}}$ & $(120 / 120)^{\mathrm{b}}$ & $(119 / 122)^{\mathrm{ab}}$ & $(62 / 72)^{\mathrm{a}}$ & $(77 / 77)^{\mathrm{b}}$ & $(73 / 75)^{\mathrm{b}}$ \\
body & $62.5 \pm 4.3$ & $72.7 \pm 2.1$ & $76.1 \pm 4.5$ & $76.8 \pm 4.3$ & $79.7 \pm 7.0$ & $77.8 \pm 5.7$ \\
Presence of metaphase & $(60 / 96)^{\mathrm{a}}$ & $(80 / 110)^{\mathrm{ab}}$ & $(89 / 117)^{\mathrm{b}}$ & $(53 / 69)^{\mathrm{a}}$ & $(59 / 74)^{\mathrm{a}}$ & $(56 / 72)^{\mathrm{a}}$ \\
plate & $43.5 \pm 7.1$ & $47.4 \pm 5.1$ & $53.5 \pm 5.0$ & $41.0 \pm 6.2$ & $39.1 \pm 7.4$ & $56.1 \pm 7.8$ \\
\hline
\end{tabular}

Mean in $\% \pm$ standard error $(n)$. a,b: differs on the same line. $\mathrm{P}<0.05$.

Figure 1. Evaluation of the presence of metaphase plate in bovine oocytes incubated with Pluset巴 FSH (FSH: LH, $1: 1)$ in the maturation medium.

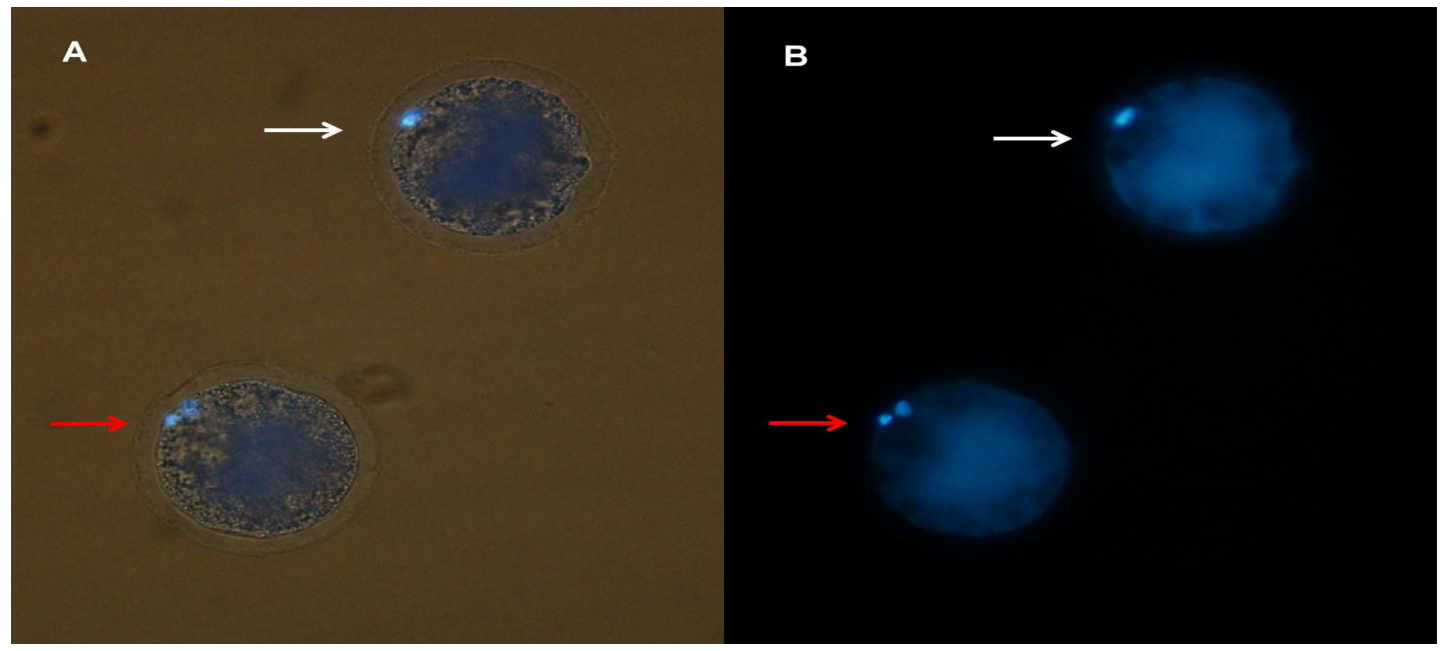

A: image in bright field. B: image in dark field. (200X). (red arrow) matured and (white arrow) not matured.

Table 3. Evaluation of oocytes incubated with Pluset ${ }^{\circledR}$ FSH and Folltropin ${ }^{\circledR}$ FSH at different concentrations $(1.0$ vs. $2.5 v s .10 .0 \mu \mathrm{g} / \mathrm{mL}$ ) during IVM for $24 \mathrm{~h}$.

\begin{tabular}{lcccccc}
\hline \multirow{2}{*}{ Evaluation of IVM } & \multicolumn{2}{c}{ Pluset巴 FSH (FSH:LH; 1:1) } & \multicolumn{3}{c}{ Folltropin $®$ FSH (FSH:LH, 5.25:1) } \\
\cline { 2 - 7 } & $\mathbf{1 . 0} \boldsymbol{\mu g} / \mathbf{m L}$ & $\mathbf{2 . 5} \boldsymbol{\mu g} / \mathbf{m L}$ & $\mathbf{1 0 . 0} \boldsymbol{\mu g} / \mathbf{m L}$ & $\mathbf{1 . 0} \boldsymbol{\mu g} / \mathbf{m L}$ & $\mathbf{2 . 5} \boldsymbol{\mu g} / \mathbf{m L}$ & $\mathbf{1 0 . 0} \mathbf{\mu g} / \mathbf{m L}$ \\
\hline \multirow{2}{*}{ Cumulus cell expansion } & $99.2 \pm 0.9$ & $99.2 \pm 0.9$ & $100 \pm 0.0$ & $100 \pm 0.0$ & $100 \pm 0.0$ & $100 \pm 0.0$ \\
Presence of the first & $(125 / 126)$ & $(121 / 122)$ & $(126 / 126)$ & $(119 / 119)$ & $(122 / 122)$ & $(120 / 120)$ \\
polar body & $61.7 \pm 6.5$ & $71.6 \pm 5.6$ & $70.2 \pm 5.3$ & $67.5 \pm 5.0$ & $63.6 \pm 5.4$ & $72.0 \pm 4.6$ \\
Presence of metaphase & $(74 / 120)$ & $(83 / 116)$ & $(85 / 121)$ & $(77 / 114)$ & $(77 / 121)$ & $(85 / 118)$ \\
plate & $65.0 \pm 1.8$ & $63.9 \pm 3.1$ & $70.9 \pm 3.1$ & $52.4 \pm 7.2$ & $58.3 \pm 4.1$ & $57.9 \pm 5.5$ \\
\hline
\end{tabular}

Mean in $\% \pm$ standard error $(n) . \mathrm{P}>0.05$. 


\section{Discussion}

In IVM, gonadotropins are the main stimulators of the oocyte development; and, FSH being deemed vital for the oocytes becomes qualified to in vitro fertilized (LU et al., 2014; KHAN et al., 2015). In this study, two different commercial representations of FSH [Pluset ${ }^{\circledR}$ vs. Folltropin $\left.{ }^{\circledR}\right]$ were evaluated on in vitro maturation of oocytes and no difference was observed between the representations when the oocytes were evaluated by the expansion of CCs, the presence of $1 \mathrm{~PB}$ and presence of the MII.

Anderiesz et al. (2000), using recombinant hormones, obtained better maturation rate when COCs were matured in $\mathrm{FSH} / \mathrm{LH}$ in a ratio of 1:1 and 1:10 compared to FSH or LH alone. Furthermore, the addition of any proportion of FSH and LH (1:1 or 1:10) in IVM improved development of embryos in the blastocyst stage (ANDERIESZ et al., 2000). However, our results suggest that when it comes to porcine FSH in standard concentration of $10 \mu \mathrm{g} /$ $\mathrm{mL}$, the proportion of $\mathrm{LH}$ (degree of purification) does not interfere in the bovine oocytes maturation rate. Saeki et al. (1990) evaluated different commercial representations of FSH porcine and ovine (NIADDK, Ausa, Sigma and Schering) at predetermined concentrations, which also was no difference in blastocyst rate ranging 20-23\%.

As for incubation time FSH, both Pluset ${ }^{\circledR}$ as Folltropin ${ }^{\circledR}$ showed lower CCs expansion rate when they were present only in the first $6 \mathrm{~h}$ of IVM. The times of $16 \mathrm{~h}$ and $24 \mathrm{~h}$ in the presence of these FSH representations shown above and similar results; however, only for Pluset ${ }^{\circledR}$ time of 24 h was similar to 6 h. Likewise, Ali and Sirard (2005) observed a higher expansion CCs after $24 \mathrm{~h}$ of incubation with rhFSH; so $6 \mathrm{~h}$ expansion is considered minimal, reaching only the last layers of cumulus.

The CCs have gonadotropin receptors that are not present in oocytes, so the presence of these cells is crucial to maintain communication with the oocyte extracellular stimulating the development (CALDER et al., 2003; GLISTER et al., 2014;
LONERGAN; FAIR, 2016). The CCs are widely used as a non-invasive assessment method of COCs quality before (compact cumulus) and after (expanded cumulus) the IVM (NEVORAL et al., 2014). However, both evaluations are considered subjective, for they can not predict the status of molecular development of oocytes (SIRARD et al., 2007; SU et al., 2012). So often it is necessary to use more precise methods of analysis that allow for greater confidence in the results, as in the case of evaluations of $1 \mathrm{~PB}$ and MII presence made in this study.

In this context, when the incubation time $(6 \mathrm{~h}$ vs. $16 \mathrm{~h}$ vs. $24 \mathrm{~h}$ ) with FSH was evaluated for the presence of $1 \mathrm{~PB}$ differences were observed in relation to Pluset ${ }^{\circledR}$, while Folltropin ${ }^{\circledR}$ showed similar results in all incubation times. Briefly, FSH Pluset ${ }^{\circledR}$ exhibited better rate of $1 \mathrm{~PB}$ when present at $24 \mathrm{~h}$ of IVM in comparison to the time of $6 \mathrm{~h}$, which were similar to the period of $16 \mathrm{~h}$. This result with Pluset ${ }^{\circledR}$ FSH can be justified because of the increased amount of LH that commercial representation, which may have influenced oocyte response. Regarding the assessment of the MII, more precise parameter analysis of IVM, there was no difference between the incubation times with FSH Pluset ${ }^{\circledR}$ and Folltropin ${ }^{\circledR}$. However, in a previous study evaluating the embryonic development of COCs matured for different times ( $2 \mathrm{~h} v s .6 \mathrm{~h} v s .24 \mathrm{~h}$ ) with rhFSH a significantly better rate of blastocysts was obtained when the hormone was only present during the first $6 \mathrm{~h}$ IVM (ALI; SIRARD, 2005). In addition, in the same study, the development of embryos to the blastocyst stage was improved by the addition of rhFSH in the first $2 \mathrm{~h}$ of IVM as compared with negative control without hormones. Furthermore, it was observed that from $6 \mathrm{~h}$ of the maturation there is a decrease in the expression of messenger RNAs coding for connexin 43 (the protein that comprise the GAP junctions in oocytes) and FSH receptors on CCs, suggesting the occurrence of decrease of stimulus maturation (CALDER et al., 2003). 
In general, the presence of FSH in the early IVM may be sufficient to trigger the necessary signaling pathways to promote nuclear and cytoplasmic maturation of cattle oocytes (SIRARD et al., 2007; KHAN et al., 2015), increasing blastocyst rates. Thus, a recent study to characterize the role of FSH on oocyte maturation used the $6 \mathrm{~h}$ incubation time (with rhFSH) as a basis for performing various molecular assays for identifying molecules involved in stimulating FSH via the CCs (KHAN et al., 2015). However, in this study, the statistical similarity of the results and the best operating conditions have led to the choice of time of $24 \mathrm{~h}$ of incubation with FSH for the next experiments.

The concentration of FSH in the medium of IVM is directly related to its origin and especially the degree of purification of the hormone (CALDER et al., 2003; JAIN et al., 2016). Typically, the more purified is the FSH best, especially when it comes to recombinant FSH (LISPI et al., 2006). In relation to animal origin $\mathrm{FSH}$, all available representations have some degree of contamination with other hormones (mainly LH), resulting in a lower cost.

In this study, there was no difference in the rate of expansion of the CCs of oocytes with different concentrations of FSH Pluset ${ }^{\circledR}$ and Folltropin $\AA$, which showed $100 \%$ of expanded COCs. Calder et al. (2003) evaluated concentrations well below pFSH (1 vs. 100 vs. $1000 \mathrm{ng} / \mathrm{mL}$ ) on the rates of expansion of CCs and observed that it was effective only at higher measured amount $(2.5 \%$ vs. $5.5 \%$ vs. $76.4 \%$, respectively). Moreover, these authors observed that for rhFSH the same concentrations (1 vs. 100 vs. $1000 \mathrm{ng} / \mathrm{mL}$ ) results were similar in the expansion of CCs $(87.3 \%$ vs. $92.1 \%$ vs. $78.7 \%$, respectively). Therefore, it is believed that the higher concentrations of pFSH used in this work were responsible for causing total cumulus expansion in most groups. Already, in buffalo, there was a higher rate of expansion of CCs when used a $5 \mu \mathrm{g} / \mathrm{mL}$ and $10 \mu \mathrm{g} / \mathrm{mL}$ of $\mathrm{pFSH}$ compared with the concentration of $1 \mu \mathrm{g} / \mathrm{mL}$ (JAIN et al., 2016).
As regards the analysis of nuclear maturation, namely the presence of a metaphase plate and $1 \mathrm{~PB}$ there was no difference between the different concentrations of FSH Pluset ${ }^{\circledR}$ and Folltropin ${ }^{\circledR}$. Similarly, Jain et al. (2016) not observed difference in the percentage of COCs showing metaphase II after IVM with 1,5 and $10 \mu \mathrm{g} / \mathrm{mL}$ of $\mathrm{pFSH}$, using the Hoechst dye. Previously, supraphysiological concentrations higher than pFSH $(10 \mu \mathrm{g} / \mathrm{mL}, 20 \mu \mathrm{g} /$ $\mathrm{mL}$ and $40 \mu \mathrm{g} / \mathrm{mL}$ ) were evaluated and a negative effect was observed (10: $81.8 \%, 20: 55.5 \%, 40$ : $50.0 \%$ ) of greater amounts of the hormone, which may have slowed or inhibited bovine oocytes maturation, decreasing the rate of metaphase II at the end of IVM; nevertheless, the authors verified no differences in cleavage and blastocyst rates (ALVES et al., 2001). In general, the concentration of $10 \mu \mathrm{g} / \mathrm{mL}$ does not have deleterious effects and so it is widely used for pFSH, justifying similar maturation rates in this study. However, it can be stated that the concentration of $1.0 \mu \mathrm{g} / \mathrm{mL}$ of FSH Pluset ${ }^{\circledR}$ or Folltropin ${ }^{\circledR}$ is sufficient to promote efficient in vitro maturation of bovine oocytes.

Other studies to evaluate the effect of different concentrations of FSH on embryonic development have been conducted. For example, Choi et al. (2001) evaluated various concentrations ranging from 0 to $15 \mathrm{ng} / \mathrm{mL}$ of FSH sheep for IVM oocytes, and no difference in blastocyst rate after 8 days of in vitro culture, even when LH was present in the medium. Recently, concentrations of $1.0 \mu \mathrm{g} / \mathrm{mL}, 5.0$ $\mu \mathrm{g} / \mathrm{mL}$ and $10 \mu \mathrm{g} / \mathrm{mL}$ of FSH in the presence of 50 or $100 \mathrm{IU} / \mathrm{mL}$ of $\mathrm{LH}$ were evaluated; where it was observed that the best concentration of FSH for IVM oocytes was $5.0 \mu \mathrm{g} / \mathrm{mL}$, regardless of the amount of LH (XIAO et al., 2014). Furthermore, it was observed that FSH alone is capable of promoting expression of membrane receptors for itself and for LH. However, only the LH was not able to promote expression of these receptors in CCs (XIAO et al., 2014). Thus, there may be a beneficial synergistic effect between these hormones also in vitro. 


\section{Conclusions}

In summary, in this study, we observed that FSH Pluset ${ }^{\circledR}$ and Folltropin ${ }^{\circledR}$ have equal efficiency when present in IVM of bovine oocytes in concentration $(10 \mu \mathrm{g} / \mathrm{mL})$ and time $(24 \mathrm{~h})$ standard. Regarding the incubation time, as there was no difference in most of the results, it is recommended to maintain FSH (Pluset ${ }^{\circledR}$ or Folltropin $\AA$ ) throughout the period of IVM, it is not so necessary to carry out medium exchange during the culture. Additionally, the concentration of $1.0 \mu \mathrm{g} / \mathrm{mL}$ of FSH Pluset ${ }^{\circledR}$ and Folltropin ${ }^{\circledR}$ is as effective as $10 \mu \mathrm{g} / \mathrm{mL}$ and can therefore be used for IVM oocytes. Finally, more studies addressing the subsequent stages of the IVEP are needed to confirm the parameters set out in this work and efficiency in obtaining quality embryos and molecular competence of oocytes cultured.

\section{Acknowledgments}

This study was supported by National Counsel of Technological and Scientific Development (CNPq, process no. 477710/2013-1).

\section{References}

ALI, A.; SIRARD, M. A. Protein kinases influence bovine oocyte competence during short-term treatment with recombinant human follicle stimulating hormone. Reproduction, Teddington, v. 130, n. 3, p. 303-310, 2005.

ALVES, J. D. R.; OLIVEIRA, M. A. L.; LIMA, P. F.; CALDAS, J. G. L.; SANTOS FILHO, A. S.; BARRETO, M. B. P. Altas concentrações de FSH-p na maturação in vitro de oócitos Bos indicus. Ciência Rural, Santa Maria, v. 31, n. 4, p. 645-649, 2001.

ANDERIESZ, C.; FERRARETTI, A. P.; MAGLI, C.; FIORENTINO, A.; FORTINI, D.; GIANAROLI, L.; JONES, G. M.; TROUNSON, A. O. Effect of recombinant human gonadotrophins on human, bovine and murine oocyte meiosis, fertilization and embryonic development in vitro. Human Reproduction, Oxford, v. 15, n. 5, p. 1140-1148, 2000.

BING, Y. Z.; NAGAI, T.; RODRIGUEZ-MARTINEZ, H. Effects of cysteamine, FSH and estradiol-17ß on in vitro maturation of porcine oocytes. Theriogenology, New York, v. 55, n. 4, p. 867-876, 2001.
BORGES, J. M. L.; RUBIN, M. I. B.; SILVA, C. A. M.; GONÇALVES, P. B. D.; RIECK, A. C. Influência das gonadotrofinas na regulação da maturação nuclear de oócitos equinos. Ciência Rural, Santa Maria, v. 28, n. 2, p. 293-297, 1998.

CALDER, M. D.; CAVENEY, A. N.; SMITH, L. C.; WATSON, A. J. Responsiveness of bovine cumulusoocyte-complexes (COC) to porcine and recombinant human FSH, and the effect of COC quality on gonadotropin receptor and $\mathrm{Cx} 43$ marker gene mRNAs during maturation in vitro. Reproductive Biology and Endocrinology, London, v. 1, n. 1, p. 14-19, 2003.

CHOI, Y. H.; CARNEVALE, E. M.; SEIDEL, G. E.; SQUIRES, E. L. Effects of gonadotropins on bovine oocytes matured in TCM-199. Theriogenology, New York, v. 56, n. 4, p. 661-670, 2001.

GLISTER, C.; HATZIRODOS, N.; HUMMITZSCH, K.; KNIGHT, P. G.; RODGERS, R. J. The global effect of follicle-stimulating hormone and tumour necrosis factor $\alpha$ on gene expression in cultured bovine ovarian granulosa cells. BMC Genomics, London, v. 15, n. 1, p. 72-87, 2014.

GONÇALVES, P. B. D.; OLIVEIRA, M. A. L.; MEZZALIRA, A.; MONTAGNER, M. M.; VISINTIN, J. A.; COSTA, L. F. S. Produção in vitro de embriões. In: GONÇALVES, P. B. D.; FIGUEIREDO, J. R.; FREITAS, V. J. F. (Ed.). Biotécnicas aplicadas à reprodução animal. São Paulo: Roca, 2008. p. 261-291.

HOOMANS, E. H. M.; ANDERSEN, A. N.; LOFT, A.; LEERENTVELD, R. A.; KAMP, A. A. V.; ZECH, H. A prospective, randomized clinical trial comparing $150 \mathrm{IU}$ recombinant follicle stimulating hormone (Puregon ${ }^{\circledR}$ ) and 225 IU highly purified urinary follicle stimulating hormone (Metrodin-HP®) in a fixed-dose regimen in women undergoing ovarian stimulation. Human Reproduction, Oxford, v. 14, n. 10, p. 2442-2447, 1999.

JAIN, A.; JAIN, T.; KUMAR, P.; KUMAR, M.; DE, S.; GOHAIN, M.; KUMAR, R.; DATTA, T. K. Folliclestimulating hormone-induced rescue of cumulus cell apoptosis and enhanced development ability of buffalo oocytes. Domestic Animal Endocrinology, Amsterdam, v. 55, n. 1, p. 74-82, 2016.

KAKKASSERY, M. P.; VIJAYAKUMARAN， V.; SREEKUMARAN, T. Effect of cumulus oocyte complex morphology on in vitro maturation of bovine oocytes. Journal of Veterinary and Animal Sciences, Pookode, v. 41, n. 1, p. 12-17, 2010.

KHAN, D. R.; GUILLEMETTE, C.; SIRARD, M. A.; RICHARD, F. J. Characterization of FSH signalling networks in bovine cumulus cells: a perspective on 
oocyte competence acquisition. Molecular Human Reproduction, Oxford, v. 21, n. 9, p. 688-701, 2015.

LISPI, M.; BASSETT, R.; CRISCI, C.; MANCINELLI, M.; MARTELLI, F.; CECCARELLI, D.; BELLIS, C. de; MENDOLA, D. Comparative assessment of the consistency and quality of a highly purified FSH extracted from human urine (urofollitropin) and a recombinant human FSH (Follitropin $\alpha$ ). Reproductive Biomedicine Online, Amsterdam, v. 13, n. 2, p. 179-193, 2006.

LONERGAN, P.; FAIR, T. Maturation of oocytes in vitro. Annual Review of Animal Biosciences, Palo Alto, v. 4, n. 1, p. 255-268, 2016.

LU, C. L.; WANG, T. R.; YAN, L. Y.; XIA, X.; ZHU, X. H.; LI, R.; ZHAO, H. C.; YAN, J.; YIN, T. L.; JIN, H. Y.; ZHANG, Y.; ZHANG, W. X.; FENG, H. L.; QIAO, J. Gonadotropin-mediated dynamic alterations during bovine oocyte maturation in vitro. Biology of Reproduction, Madison, v. 91, n. 2, p. 1-9, 2014.

MACHATY, Z.; PEIPPO, J.; PETER, A. Production and manipulation of bovine embryos: techniques and terminology. Theriogenology, New York, v. 78, n. 5, p. 937-950, 2012.

NEVORAL, J.; ORSÁK, M.; KLEIN, P.; PETR, J.; DVOŘÁKOVÁ, M.; WEINGARTOVÁ, I.; VYSKOČILOVÁ, A.; ZÁMOSTNÁ, K.; KREJČOVÁ, T.; JÍLEK, F. Cumulus cell expansion, its role in oocyte biology and perspectives of measurement: A review. Scientia Agriculturae Bohemica, Czech Republic, v. 45, n. 4, p. 212-225, 2014.
RIOS, G. L.; BUSCHIAZZO, J.; MUCCI, N. C.; KAISER, G. G.; CESARI, A.; ALBERIO, R. H. Combined epidermal growth factor and hyaluronic acid supplementation of in vitro maturation medium and its impact on bovine oocyte proteome and competence. Theriogenology, Stoneham, v. 83, n. 5, p. 874-880, 2015.

SAEKI, K.; HOSHI, M.; LEIBFRIED-RUTLEDGE, M. L.; FIRST, N. L. In vitro fertilization and development of bovine oocytes matured with commercially available follicle stimulating hormone. Theriogenology, New York, v. 34, n. 1, p. 1035-1039, 1990.

SHIRAZI, A.; SHAMS $\square$ ESFANDABADI, N.; AHMADI, E.; HEIDARI, B. Effects of growth hormone on nuclear maturation of ovine oocytes and subsequent embryo development. Reproduction in Domestic Animals, Linköping, v. 45, n. 3, p. 530-536, 2010.

SIRARD, M. A.; DESROSIER, S.; ASSIDI, M. In vivo and in vitro effects of FSH on oocyte maturation and developmental competence. Theriogenology, New York, v. 68S, n. 2, p. S71-S76, 2007.

SU, J.; WANG, Y.; LI, R.; PENG, H.; HUA, S.; LI, Q.; QUAN, F.; GUO, Z.; ZHANG, Y. Oocytes selected using $\mathrm{BCB}$ staining enhance nuclear reprogramming and the in vivo development of SCNT embryos in cattle. Plos One, Nevada, v. 7, n. 4, p. 1-10, 2012.

XIAO, X.; ZI, X. D.; NIU, H. R.; XIONG, X. R.; ZHONG, J. C.; LI, J.; WANG, L.; WANG, Y. Effect of addition of FSH, LH and proteasome inhibitor MG132 to in vitro maturation medium on the developmental competence of yak (Bos grunniens) oocytes. Reproductive Biology and Endocrinology, London, v. 12, n. 12, p. 1-7, 2014. 
